\title{
Pro-opiomelanocortin Messenger Ribonucleic Acid and Posttranslational Processing of Beta Endorphin in Spleen Macrophages
}

\author{
Stephen J. Lolait, Judith A. Clements, Alison J. Markwick, Chris Cheng, Margaret McNally, \\ A. lan Smith, and John W. Funder \\ Medical Research Centre, Prince Henry's Hospital, Melbourne, Australia
}

\begin{abstract}
We have previously demonstrated low levels of immunoreactive (ir)- $\beta$-endorphin ( $\beta$-EP) and ir-ACTH in a subpopulation of mouse spleen macrophages, which is consistent with an involvement of opioid peptides in modulation of immune responses. Gel chromatography studies suggested the presence of an $\sim 3.5,000$ molecular weight (mol wt) species, putatively $\beta$-EP, an $\sim$ 11.5,000-mol-wt species, putatively $\beta$-lipotropin, and a higher molecular weight species (putative $\beta$-EP precursor, pro-opiomelanocortin (POMC)). In this study we have extended our original findings by demonstrating the presence of messenger RNA for POMC by the use of a complementary DNA probe and Northern blot analysis of extracts of mouse and rat spleen. In addition, using high performance liquid chromatography (HPLC), we have shown that the major endorphin species in mouse spleen macrophages is $\beta-\mathbf{E P}_{1-31}$, and that there are smaller amounts of each of the acetylated forms, $N$-acetyl- $\beta$-EP $\mathbf{P}_{1-16}$ ( $\alpha$-endorphin), $N$-acetyl- $\beta$-EP $\mathbf{E P}_{1-17}$ ( $\gamma$-endorphin), $N$-acetyl- $\beta$ $\mathbf{E P}_{1-27}$, and $N$-acetyl- $\beta-\mathbf{E P}_{1-31}$. We interpret these studies as showing that $(a)$ the spleen is an organ of POMC synthesis and that $(b)$ the predominant $\mathrm{COOH}$-terminal product of macrophage POMC is the opiate-receptor active species $\beta-\mathbf{E P}_{1-31}$.
\end{abstract}

\section{Introduction}

There are a number of recent observations indicating that derivatives of pro-opiomelanocortin (POMC) ${ }^{1}$ may have a role in the modulation of immune responsiveness (1-3). In particular, $\beta$-endorphin ( $\beta$-EP) has been reported to enhance the proliferative response of rat T lymphocytes to mitogens (4), and ACTH and $\alpha$-endorphin to suppress in vitro antibody production to $\mathrm{T}$ cell-dependent and T cell-independent antigens (5). Similarly, human peripheral blood leukocytes and mouse spleen cells have been reported to produce ACTH- and $\gamma$-endorphin-related material in response to virus infections $(6,7)$. We have recently shown that a subpopulation of mouse spleen macrophages contain small amounts of immunoreactive (ir)- $\beta$-EP, ir-ACTH, and

Address correspondence to Dr. Funder, Medical Research Centre, Prince Henry's Hospital, St. Kilda Rd., Melbourne, Victoria, Australia 3004.

Received for publication 3 October 1985 and in revised form 31 December 1985.

Received for publication 3 October 1985 and in revised form 31 December 1985.

1. Abbreviations used in this paper: $\beta$-EP, $\beta$-endorphin; bp, base pair; HPLC, high performance liquid chromatography; ir, immunoreactive; $N$ ac-EP, $N$-acetyl-endorphin; poly $(\mathrm{A})^{+}$, polyadenylated; POMC, proopiomelanocortin; TFA, trifluoroacetic acid.

J. Clin. Invest.

(c) The American Society for Clinical Investigation, Inc.

0021-9738/86/06/1776/04 \$1.00

Volume 77, June 1986, 1776-1779 presumptive higher molecular weight forms of both (8); the molecular nature of the ir- $\beta$-EP species was, however, not characterized in that study.

In the present study, we have used specific $\beta$-EP and $\alpha-N$ acetyl endorphin radioimmunoassays, and reverse-phase high performance liquid chromatography (HPLC), to establish that $\beta-\mathrm{EP}_{1-31}$ is the major form of ir-endorphin in mouse spleen macrophages, and that only small amounts of acetylated endorphins are present. In addition, we have confirmed that the spleen is a site of POMC synthesis by demonstrating, with Northern blot analysis, the presence of POMC messenger RNA in this tissue.

\section{Methods}

HPLC. Macrophages were obtained from the spleens of 6-8-wk-old female Balb/c mice as previously described (8). Cells from 12 cultures (2 $\times 10^{5}$ macrophages/culture) were extracted in ice-cold $0.1 \mathrm{~N} \mathrm{HCl}$ by repetitive freeze-thawing on liquid nitrogen. For oxidation studies, extracts were exposed for $30 \mathrm{~min}$ to $1 \mathrm{mM} \mathrm{NaIO}_{4}$ in $50 \%$ acetic acid. For HPLC, supernatants from extracted cells were lyophilized, resuspended in 11 mM trifluoroacetic acid (TFA), and subjected to HPLC on a Nova Pak radially compressed $\mathrm{C}_{18}$ cartridge (Waters Associates, Millipore Corp., Milford, MA), as previously described (9-11). The column was eluted with a linear gradient of $30-80 \%$ solvent $B$ over $30 \mathrm{~min}$ at $1.0 \mathrm{ml} / \mathrm{min}$. Solvent A consisted of $11 \mathrm{mM}$ TFA, $3.6 \mathrm{mM}$ acetic acid, and solvent $B$ consisted of $70 \%$ acetonitrile, $11 \mathrm{mM}$ TFA. Fractions $(0.5 \mathrm{ml})$ were collected, evaporated, and reconstituted in the appropriate buffer for $\beta$-EP or $N$-acetyl-endorphin ( $N$ ac-EP) radioimmunoassay. Recoveries of both iodinated tracer and standards were $>85 \%$ after cell extraction and HPLC procedures.

Radioimmunoassay. Characteristics and specificity of the $\beta$-EP and $N$ ac-EP radioimmunoassays have been previously described in detail $(10-13)$. The primary antibody (R56) employed in $\beta$-EP radioimmunoassay studies was raised against synthetic ovine $\beta$-EP ${ }_{1-31}$ (Peninsula Laboratories, Inc., Belmont, $C A)$ and recognizes the undecapeptide sequence $\beta-\mathrm{EP}_{17-27}$. It recognizes $\beta-\mathrm{EP}_{1-31}, \beta-\mathrm{EP}_{1-27}$, and their acetylated derivatives equivalently on a molar basis, but fails to recognize $\alpha$-EP, $\gamma$-EP, or $N$-acetylated forms of these shorter peptides. The primary antiserum (R92) used in Nac-EP studies was raised against synthetic ovine

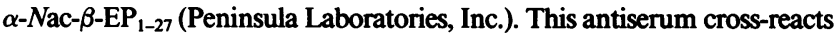
$100 \%$ with $\alpha-N a c-\alpha$-EP and longer acetylated $\mathrm{COOH}$-terminal forms of endorphin. Neither R56 or R92 recognize ACTH ${ }_{1-39}, \alpha-\mathrm{MSH}\left(\mathrm{ACTH}_{1-13}\right.$ corticotropin-like intermediate lobe peptide amide), CLIP, met-enkephalin, or leu-enkephalin.

Complementary DNA hybridization studies. Pituitaries and spleens were collected from female Balb/c mice and Sprague-Dawley rats, snapfrozen in liquid nitrogen, and stored at $-80^{\circ} \mathrm{C}$ until processed. Total RNA was isolated from pooled tissues by homogenization in $5 \mathrm{M}$ guanidine thiocyanate $/ 5 \% \beta$-mercaptoethanol and centrifugation through $5.7 \mathrm{M}$ cesium chloride (14). The resultant RNA pellet (except for mouse pituitaries) was resuspended, ethanol-precipitated, and passed over an oligo-dT cellulose affinity column to yield polyadenylated $\left(\operatorname{poly}(\mathbf{A})^{+}\right)$ RNA (15). The low levels of total RNA in mouse pituitaries were insufficient for oligo-dT affinity chromatography.

Northern blotting was performed as previously described $(16,17)$. Poly(A) ${ }^{+}$RNA (1-10 $\left.\mu \mathrm{g}\right)$ or total RNA (2 $\left.\mu \mathrm{g}\right)$ from each tissue was denatured in $1 \mathrm{M}$ glyoxal/50\% dimethylsulfoxide, electrophoresed on a 
1.2\% agarose horizontal gel in $10 \mathrm{mM}$ sodium phosphate buffer, $\mathrm{pH} 7.0$, and then blotted onto a Biodyne nylon membrane (Pall Process Filtration, Portsmouth, United Kingdom) before baking at $80^{\circ} \mathrm{C}$ for $2 \mathrm{~h}$. A 550 base pair cDNA (I13) encoding the $3^{\prime}$ terminal regions of the rat POMC gene, including the ACTH and $\beta$-EP coding sequences (18) (gift of Dr. J. Roberts, Columbia University, New York, NY) was radiolabeled with [ $\left.\alpha-{ }^{32} \mathrm{P}\right]$ deoxycytidine triphosphate $(3,500 \mathrm{Ci} / \mathrm{mmol}$; Amersham, United Kingdom) to high specific activity $\left(\sim 10^{7} \mathrm{cpm} / \mu \mathrm{g}\right.$ DNA) by nick translation (Nick Translation Kit, Amersham). After prehybridization overnight at $42^{\circ} \mathrm{C}$, the blot was incubated with the ${ }^{32} \mathrm{P}$-labeled cDNA probe diluted in hybridization buffer (16) for $48 \mathrm{~h}$ at $42^{\circ} \mathrm{C}$, then washed sequentially in $2 \times \mathrm{SSC} / 0.1 \%$ sodium dodecyl sulfate $(1 \times \mathrm{SSC}$ is $0.15 \mathrm{M}$ sodium chloride, $0.015 \mathrm{M}$ sodium citrate, $\mathrm{pH}$ 7.4) at room temperature, and $0.1 \times \mathrm{SSC} / 0.1 \%$ sodium dodecyl sulfate at room temperature and $50^{\circ} \mathrm{C}$. For subsequent reprobing, a recombinant plasmid (prGH-1) containing an 800 base pair (bp) insert, encoding rat growth hormone sequences in the Hind III site of pBR322 (gift of Dr. J. Shine, Australian National University, Canberra, Australia), was used. Gels were washed at $65^{\circ} \mathrm{C}$ for $2 \mathrm{~h}$ in $0.1-0.05$ wash solution $(1 \mathrm{x}$ wash solution contains $50 \mathrm{mM}$ Tris- $\mathrm{HCl}$ at $\mathrm{pH} 8.0,2 \mathrm{mM}$ EDTA, $0.5 \%$ sodium pyrophosphate, and $0.02 \%$ bovine serum albumin, Ficoll, and polyvinylpyrollidone) (16, 17), and then prehybridized and hybridized as before. The presence of ${ }^{32} \mathrm{P}-\mathrm{cDNA} / \mathrm{mRNA}$ hybrids was revealed by autoradiography with Kodak X-AR film (Eastman Kodak Co., Rochester, NY) with Cronex Lightning Plus intensifying screens (E. I. Du Pont de Nemours \& Co., Wilmington, $\mathrm{DE})$ at $-70^{\circ} \mathrm{C}$ for $15 \mathrm{~d}$.

\section{Results}

In mouse spleen macrophages, ir-Nac-EP levels are $\sim 50 \%$ lower $\left(\sim 1 \mathrm{ng} / 1 \times 10^{6}\right.$ cells $)$ than ir- $\beta$-EP levels reported previously (8). On HPLC, the predominant form of $\beta$-EP-immunoreactivity is $\beta$-EP ${ }_{1-31}$ (Fig. $1 A$ ). The major form of Nac-EP-immunoreactivity is $N$ ac- $\gamma$-EP, with smaller but distinct peaks of $N$ ac- $\alpha$-EP, $N a c-\beta-E_{1-31}$, and $N$ ac- $\beta$-EP ${ }_{1-27}$ (Fig. $1 B$ ). The minor peaks on each side of Nac- $\alpha$-EP (labeled 1 and 2), co-elute with the methionine sulfoxide forms of synthetic ovine $N a c-\alpha$-EP and Nac$\gamma$-EP (10). These peaks would therefore appear to be caused by partial oxidation of the macrophage samples during extraction. Extracts oxidized with $\mathrm{NaIO}_{4}$ before HPLC showed a marked diminution in $N$ ac- $\alpha$-EP and $N$ ac- $\gamma$-EP peaks, and concomitant rises in peaks 1 and 2 .

Hybridization of the rat POMC cDNA probe to rat pituitary whole RNA (lane 1 ), poly (A) ${ }^{+}$RNA (lane 5), and spleen poly $(A)^{+}$RNA (lane 4) is shown in Fig. 2. Hybridization bands can also be observed for mouse pituitary total RNA (lane 2) and spleen poly (A) ${ }^{+}$RNA (lane 3 ). This is not an unexpected finding, given the highly homologous genomic sequences previously reported for rat (19) and mouse (20) POMC. Although the pituitary RNA hybridization is overexposed in comparison with that seen for spleen RNA, and there is some degradation apparent in the mouse preparations, it is evident that the single band present for the spleen poly (A) ${ }^{+}$RNA is of a size similar in both species to that of pituitary POMC mRNA $(\sim 1100 \mathrm{bp}(21))$. In the lower panel, the hybridization of rat growth hormone cDNA to the rat pituitary total RNA (lane 1 ) and poly (A) ${ }^{+}$RNA (lane 5), as well as to mouse pituitary total RNA (lane 2) can be seen; no hybridization to spleen mRNA preparations, however, is present (lanes 3, 4).

\section{Discussion}

In the present studies, we have extended our original findings (8) by showing that $\beta-E P_{1-31}$ is the major ir-endorphin species

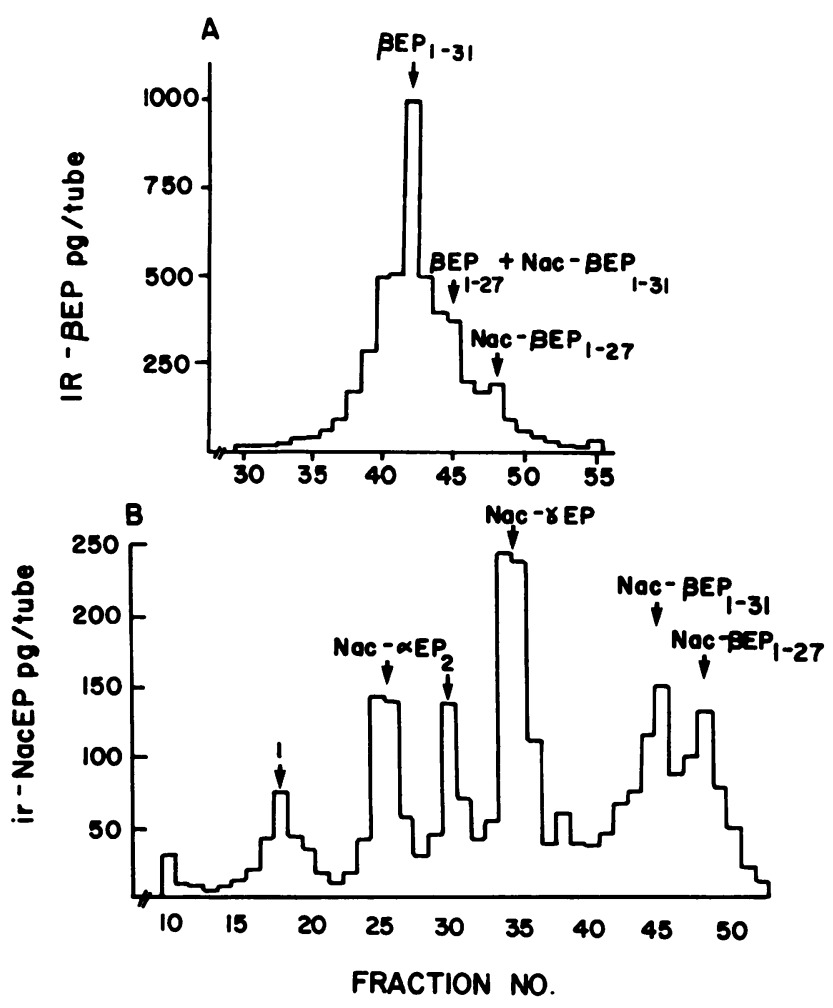

Figure 1. Profile of $\beta$-EP (antiserum R56; panel $A$ ) and Nac-EP (antiserum R92; panel $B$ ) immunoreactivity after reverse-phase HPLC of spleen macrophage cell extracts. Fractions were collected at 0.5 -min intervals; the elution time of synthetic standards was determined by ultraviolet absorbance at $214 \mathrm{~nm}$ in separate runs.

in the spleen. A considerable proportion of the ir-endorphin is $\mathrm{N}$-acetylated, as has been shown to be the case for the intermediate lobe of the rat pituitary (22) and testis (10), but not for the rat brain (22). Nac- $\beta$-EP ${ }_{1-31}, N a c-\beta-E_{1-27}$, and $N a c-\beta-E_{1-26}$ are the major end products of POMC processing in the intermediate lobe, while in the testis shorter acetylated endorphin derivatives predominate. In contrast with both these tissues, the $N$-acetylated endorphin immunoreactivity in spleen macrophages consists of both long $\left(\beta-\mathrm{EP}_{1-31}\right.$ and $\left.\beta-\mathrm{EP}_{1-27}\right)$ and short $\left(\beta\right.$-EP ${ }_{1-16}(\alpha-E P)$ and $\beta$-EP ${ }_{1-17}(\gamma$-EP)) forms. The major $N$-acetylated form is $N$ ac- $\gamma$-EP, as observed in the testis, with $N a c-\beta$ $\mathrm{EP}_{1-31}, N \mathrm{ac}-\beta-\mathrm{EP}_{1-27}$, and $N \mathrm{ac}-\alpha-\mathrm{EP}$ at similar levels.

The physiological significance of the presence of both acetylated and nonacetylated forms of endorphin in spleen macrophages is not known. We have previously suggested that macrophage endorphins may exert a local immune regulatory role in the spleen microenvironment (8). In vitro, endorphins suppress $B$ lymphocyte antibody responses by an action on opiatespecific receptors (5), whereas the augmentation of $T$ lymphocyte mitogenesis by $\beta$-EP is neither mimicked by opiates or enkephalins nor blocked by naloxone, and hence does not appear to be mediated by classical opiate receptors (4). Since $N$-acetylation renders endorphins opiate receptor-inactive, it may be that macrophage $\beta-E P_{1-31}$ has a role in regulating $B$ cell functions, while macrophage $N$-acetylated endorphins are involved in modulating $T$ cell responses to mitogens. These putative actions are feasible in the spleen, an organ with a specialized microen- 

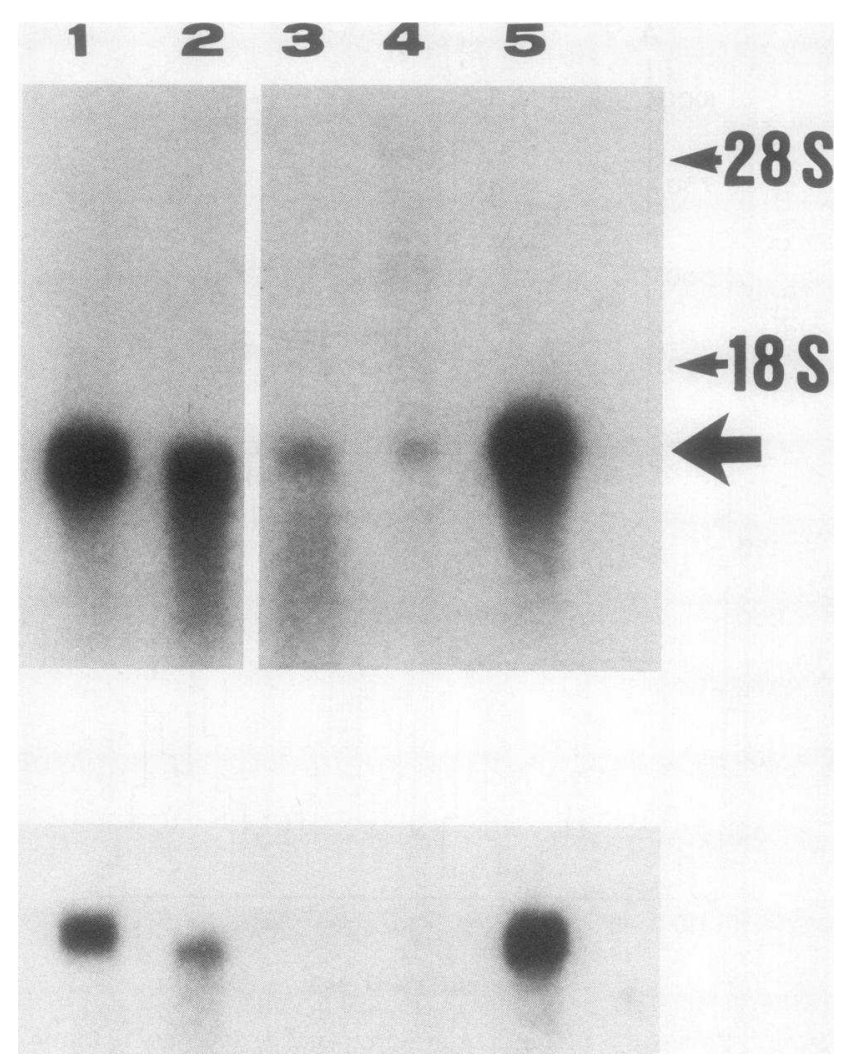

Figure 2. Hybridization of ${ }^{32} \mathrm{P}$-labeled rat POMC cDNA probe (upper panel) and rat growth hormone cDNA probe (lower panel) to $2 \mu \mathrm{g}$ of rat pituitary (lane 1 ) and mouse pituitary (lane 2) total RNA, $10 \mu \mathrm{g}$ of mouse and rat spleen poly (A) $)^{+}$RA (lanes 3 and 4, respectively), and $1 \mathrm{~g}$ of rat pituitary poly (A) ${ }^{+}$RNA (lane 5 ). Hybridization to the 1,100 bp POMC mRNA is shown by the arrow, and to residual $18 \mathrm{~s}$ and 28 $s$ ribosomal RNA as indicated. Autoradiography was for $15 \mathrm{~d}$ with Kodak X-AR film plus intensifying screen at $-70^{\circ} \mathrm{C}$.

vironment that allows close collaboration between $\mathrm{T}$ cells, B cells, and macrophages (23). It is also possible that $\mathrm{N}$-acetylation may act as a disposal mechanism, lowering levels of opiate receptor-active ligands.

In the present studies, we have also shown the presence of POMC mRNA, of a size similar to that found in the pituitary, in spleen tissue. The size of the spleen POMC mRNA $(\sim 1100$ $\mathrm{bp)}$ demonstrated here is longer than that previously reported for several other nonpituitary sites of POMC synthesis (testis and ovary, $\sim 900 \mathrm{bp}(24,25)$; amygdala, midbrain, and cerebral cortex, 1,000 bp (21)), but is similar, if not identical, to that described for hypothalamic, as well as pituitary, POMC mRNA $(18,21)$. The difference in POMC mRNA size suggests that the tissue-specific differences in POMC processing evident in the spleen may occur posttranslationally, whereas in the other nonpituitary sites of POMC synthesis so far described, tissue-specific differences in RNA processing or other transcriptional events may also occur.

Ir-endorphin is localized in macrophages but is undetectable in spleen lymphocytes, since the macrophage is the source of spleen POMC. Taken together with macrophage cell culture studies, where a significant increase in macrophage endorphin content is demonstrable over time (8), this observation provides additional evidence that local synthesis of POMC occurs in the spleen. The relative tissue abundance of POMC mRNA levels (determined from hybridization intensities in Fig. 2) suggests that the level of expression of the POMC gene in the spleen is at least $\sim 1,000$-fold less than that in the pituitary, consistent with the $\sim 1,000$-fold difference in levels of ir-endorphin in the two tissues (8). Whether these levels, or patterns of acetylation, alter in response to macrophage activation awaits exploration; the results of such studies may provide further insight into the role of macrophage-derived endorphins in lymphoid tissues.

\section{Acknowledgments}

We thank Joan Williams for typing the manuscript and Anne Saunders for artwork.

This work was supported by the National Health and Medical Research Council of Australia.

\section{References}

1. Chang, K.-J. 1984. Opioid peptides have actions on the immune system. Trends Neurosci. 7:234-235.

2. Blalock, J. E. 1984. The immune system as a sensory organ. $J$. Immunol. 132:1067-1070.

3. Blalock, J. E., and E. M. Smith. 1985. The immune system: our mobile brain? Immunol. Today. 6:115-117.

4. Gilman, S. C., J. M. Schwartz, R. J. Milner, F. E. Bloom, and J. D. Feldman. 1982. $\beta$-Endorphin enhances lymphocyte proliferative responses. Proc. Natl. Acad. Sci. USA. 79:4226-4230.

5. Johnson, H. M., E. M. Smith, B. A. Torres, and J. E. Blalock. 1982. Regulation of the in vitro antibody response by neuroendocrine hormones. Proc. Natl. Acad. Sci. USA. 79:4171-4174.

6. Smith, E. A., and J. E. Blalock. 1981. Human lymphocyte production of corticotropin and endorphin-like substances: association with leucocyte interferon. Proc. Natl. Acad. Sci. USA. 78:7530-7534.

7. Smith, E. A., W. J. Meyer, and J. E. Blalock. 1982. Virus-induced corticosterone in hypophysectomized mice: a possible lymphoid adrenal axis. Science (Wash. DC). 281:1311-1312.

8. Lolait, S. J., A. T. Lim, B. H. Toh, and J. W. Funder. 1984. Immunoreactive $\beta$-endorphin in a subpopulation of mouse spleen macrophages. J. Clin. Invest. 73:277-280.

9. Smith, A. I., and J. R. McDermott. 1984. High-performance liquid chromatography of neuropeptides using radially compressed polythene cartridges. J. Chromatogr. 306:99-108.

10. Cheng, M. C., J. A. Clements, A. I. Smith, S. J. Lolait, and J. W. Funder. 1985. $N$-acetyl endorphin in rat spermatogonia and primary spermatocytes. J. Clin. Invest. 75: 832-835.

11. Lolait, S. J., D. J. Autelitano, A. T. W. Lim, A. I. Smith, B. H. Toh, and J. W. Funder. 1985. Ovarian immunoreactive $\beta$-endorphin and estrous cycle in the rat. Endocrinology. 117:161-168.

12. Lim, A. T., B. A. K. Khalid, J. Clements, and J. W. Funder. 1982. Glucocorticoid and mineralocorticoid effects on adrenocorticotropin and $\beta$-endorphin in the adrenalectomized rat. J. Clin. Invest. 69: 1191-1198.

13. Lim, A. T., S. Lolait, J. W. Barlow, W.-S. O, I. Zois, B. H. Toh, and J. W. Funder. 1983. Immunoreactive $\beta$-endorphin in the sheep ovary. Nature (Lond.). 303:709-711.

14. Chirgwin, J. M., A. E. Przybyla, R. J. MacDonald, and W. J. Rutter. 1979. Isolation of biologically active ribonucleic acid from sources enriched in ribonuclease. Biochemistry. 18:5294-5299.

15. Aviv, H., and P. Leder. 1972. Purification of biologically active globin messenger RNA by chromatography on oligothymidylic acid-cellulose. Proc. Natl. Acad. Sci. USA. 69:1408-1412. 
16. Thomas, P. S. 1980. Hybridization of denatured RNA and small DNA fragments transferred to nitrocellulose. Proc. Natl. Acad. Sci. USA. 77:5201-5205.

17. Fuller, P. J., J. A. Clements, P. L. Whitfield, and J. W. Funder. 1985. Kallikrein gene expression in the rat anterior pituitary. Mol. Cell. Endocr. 39:99-105.

18. Chen, C.-L. C., F. R. Dionne, and J. L. Roberts. 1983. Regulation of the pro-opiomelanocortin mRNA levels in rat pituitary by dopaminergic compounds. Proc. Natl. Acad. Sci. USA. 80:2211-2215.

19. Drouin, J., and H. M. Goodman. 1983. Most of the coding region of rat ACTH/ $\beta$-LPH precursor gene lacks intervening sequences. Nature (Lond.). 288:610-613.

20. Uhler, M., E. Herbert, P. D'Eustachio, and F. D. Ruddle. 1983. The mouse genome contains two non-allelic pro-opiomelanocortin genes. J. Biol. Chem. 258:9444-9453.
21. Civelli, O., N. Birnberg, and E. Herbert. 1982. Detection and quantitation of pro-opiomelanocortin mRNA in pituitary and brain from different species. J. Biol. Chem. 257:6783-6787.

22. Zakarian, S., and D. G. Smyth. 1982. $\beta$-endorphin is processed differently in specific regions of rat pituitary and brain. Nature (Lond.). 296:250-252.

23. Roitt, I. M. 1980. Essential Immunology. Blackwell Scientific Publications, Oxford, United Kingdom. 47-100.

24. Pintar, J. E., B. S. Schacter, A. B. Herman, S. Durgerian, and D. T. Krieger. 1984. Characterization and localization of proopiomelanocortin messenger RNA in the adult rat testis. Science (Wash. DC). 225:632-634.

25. Chen, C.-L. C., and C.-C. Chang. 1985. Expression and regulation of pro-opiomelanocortin gene in the ovary and placenta. Proc. 67th Annu. Meet. Endocr. Soc. 515 (Abstr.) 